\title{
Judicial Review and the Politico-legal Constitution
}

\author{
Anne Richardson Oakes ${ }^{1}$ \\ Birmingham City University, United Kingdom
}

\begin{abstract}
The decision of the British people in 2016 that the U.K. should leave the European Union has inaugurated a period of intense debate concerning the future development of the U.K.'s notoriously 'flexible' constitutional arrangements and specifically the relationship between Montesquieu's three branches of government, the legislature, the executive and the judiciary. The decisions of the U.K. Supreme Court in R. (Miller) v. Secretary of State for Exiting the European Union and R. (Miller) v. Prime Minister provoked widespread anger and political commitments to curb judicial overreach. This paper reflects on the implications for the future development of judicial review in U.K. constitutionalism. It notes that attempts to mine the common law heritage for constitutional principles may indicate attempts by the U.K. Supreme Court to anticipate U.K. withdrawal from the jurisdiction of the European courts but suggests that in a turbulent political climate, judicial review will do well to refocus away from the constitutionalism of recent years in favour of a more traditionally restrained role that will demonstrate respect for the political choices of the electorate's chosen representatives
\end{abstract}

Keywords: Legal Constitutionalism, R.(Miller) v. Secretary of State for Exiting the European Union, R. (Miller) v. Prime Minister.

Contents: 1. Introduction. 2. Towards a Legal Constitution. 3. Rebalancing the Separation of Powers in a Politico-Legal Constitution.

\section{INTRODUCTION}

The decision of the British people in 2016 that the U.K. should leave the European Union has inaugurated a period of intense debate concerning the future development of the U.K.'s notoriously 'flexible' constitutional arrangements and specifically the relationship between Montesquieu's three branches of government, the legislature, the executive and the judiciary. The decision of the Cameron administration to hold what was only the third ever referendum was widely criticised at the time on the basis that the commitment to popular sovereignty that it represented sits uneasily with the constitutional orthodoxy of parliamentary sovereignty. However, it was the political turmoil that followed the implementation attempts by Prime Minister May and her successor Boris Johnson that brought the judiciary into the fray

\footnotetext{
${ }^{1}$ Director, Centre for American Legal Studies, Birmingham City University. Anne.oakes@ bcu.ac.uk
} 
and produced what are widely regarded as the two most important constitutional rulings of our time. The decisions of the Supreme Court that the U.K. government had acted unlawfully in its decisions to initially trigger Article 50 without recourse to Parliament ${ }^{2}$ and then, more recently, to prorogue Parliament itself $f^{3}$ provoked accusations of judicial overreach and widespread anger in Conservative party circles now reflected in a manifesto promise of judicial review reform that will "restore trust in our institutions and in how our democracy operates" and "ensure that judicial review is available to protect the rights of the individuals against an overbearing state, while ensuring that it is not abused to conduct politics by another means or to create needless delays."4

What exactly the Conservative government has in mind remains to be seen. At the time of writing the promised Constitution, Democracy \& Rights Commission has yet to materialise. However, taken in conjunction with proposals to "update" the Human Rights Act 1998 which incorporates the European Convention on Human Rights into U.K. law and now grounds many judicial review challenges brought against government policies, the concern is expressed that what is at issue here is a politically motivated desire for revenge intended to clip the wings of the judiciary and thereby threaten judicial independence and with it the rule of law. ${ }^{5}$ As Professors Harlow and Rawlings point out, these threats are not without precedent. ${ }^{6}$ The Criminal Justice and Courts Act 2015 in combination with changes to the Civil Procedure Rules introduced significant restrictions on the availability of judicial review proceedings motivated by a perception that "judicial review has become too much of a political tool of opposition to government policy." "In the words of then Justice Secretary Chris Grayling, judicial review should not be "a promotional tool for countless Left-wing campaigners." 8

It is common to reject assertions of judicial politicisation as misplaced because they conflate the nature of the court's decision which is concerned with process with the political merits of of the decision which is under review. As has been pointed out, "all judicial review proceedings are the result of politics of some kind [...] [and] no claimant bringing a judicial review ever agrees with substantive decision that they are challenging — they simply wouldn't

\footnotetext{
${ }^{2}$ R. (Miller) v. Secretary of State for Exiting the European Union [2017] UKSC 5 (Miller I).

${ }^{3}$ R. (Miller) v. Prime Minister [2019] UKSC (41) (Miller II).

${ }^{4}$ Conservative \& Unionist Party Manifesto 48 (2019).

5 See Jane Croft \& James Blitz, Lawyers Fear Tories Are Planning 'Revenge' Against the Supreme Court, FinanCIAL TimES (Dec. 11, 2019).

${ }^{6}$ Carol Harlow \& Richard Rawlings, 'Striking Back' and 'Clamping Down': An Alternative Perspective on Judicial Review, in Public Law Adjudication in Common Law Systems: Process and Substance 312 (John Bell et al. eds., 2015).

${ }^{7}$ Constitution Committee, Criminal Justice and Courts Bill, HL 18 (2014) [6].

${ }^{8}$ Chris Grayling, The Judicial Review System is not a Promotional Tool for Countless Left-wing Campaigners, DAILY MAIL (Sept. 6, 2013).
} 
bother otherwise." What is important, however, is the statement that follows: "the Courts ... determine such proceedings on the basis of the lawfulness of the public decision, not its substance. And that is the beginning and end of judicial review - it is a supervisory process to ensure that public decisions are taken lawfully, not a means for the Court to substitute its own judgement for that of the decision-maker." 10 As a statement of constitutional orthodoxy this is an uncontroversial acknowledgment that the judicial role vis à vis the political decisions of the executive should be one of respect for, or deference to, the choices of the people's elected representatives or those answerable to them. In terms of practical application, however, the history of the development of judicial review in the U.K. since 1978 suggests that the line between supervision of process and review of substance is easily crossed and indeed in many cases should be crossed if the requirements of U.K. human rights law obligations are to be satisfied. The point then for this paper is that, for its detractors, judicial review has become and is seen to have become insufficiently 'deferential' and thereby overstepped the boundaries of its constitutional role.

\section{TOWARDS A Legal CONSTITUTION}

The U.K. famously has no written Constitution. In its absence, traditional orthodoxy describes the constitution of the United Kingdom as political rather than legal ${ }^{11}$ because the primary channels of governmental accountability run to the legislature via political mechanisms of control, as opposed by the judiciary. ${ }^{12}$ In the words of Professor Tomkins, "[a] political constitution is one in which those who exercise political power (let us say the government) are held to constitutional account through political means, and through political institutions (for example, Parliament)." In contrast, a legal constitution is “one which imagines that the principal means, and the principal institution, through which the government is held to account is the law and the court-room."13 While it is true that in terms of our constitutional history, the tension between the political and legal institutional mechanisms of accountability has been resolved in favour of the former, it is also true that the development of a review

\footnotetext{
${ }_{9}^{9}$ See Michael Dempsey, General Election 2019: Judicial Review Reform for Brexit Britain? BRYAN CAVE LEIGHTON PAISNER (Dec.3, 2019).

${ }^{10} I d$.

${ }^{11}$ See, e.g., Graham Gee \& Gregoire C.N. Webber, What Is a Political Constitution? 30 Oxford J. Leg. Studies 273 (2010); Adam Tomkins, In Defence of the Political Constitution, 22 OXFord J. LeG. STUDIES 157 (2002); Adam Tomkins, What's Left of the Political Constitution, 14 GERMAN L.J. 2275 (2013).

${ }^{12}$ See Adam Tomkins, Public Law 18-19 (2003).

${ }^{13} I d$.
} 
jurisprudence for the protection of fundamental rights which anticipated but predated the coming into effect of the Human Rights Act 1998 has materially shifted the balance. The willingness of the U.K. Supreme Court to deploy the common law heritage in this endeavour may be explained in terms of prescience and expediency-as Professor Elliott observes, the effect of recent case law is that

it is hard to resist concluding that senior judges are laying the ground for possible HRA repeal and ECHR withdrawal, and that, in doing so, they are ensuring that the underlying common law landscape that would be laid bare in such circumstances would turn out to embody a set of human rights protections comparable to those that obtain today 14

In constitutional terms the overall effect indicates a significant change of emphasis in favour of the legal constitution, ${ }^{15}$ albeit without its ultimate sanction - no judge has as yet attempted to declare an Act of Parliament to be unconstitutional. ${ }^{16}$

\section{Rebalancing the Separation of Powers in a Politico-Legal Constitution}

As the fallout from the Miller judgments continues to make waves, ${ }^{17}$ this paper considers the position of the judiciary vis à vis the executive from the perspective of what Professor Richard Mullender identifies as a "dispositional" element in the U.K. constitutional order This, he claims, "finds expression in the effort to identify contingencies (most obviously, internal and external threats) that may disrupt the order's operations or even compromise its

\footnotetext{
${ }^{14}$ Mark Elliott, Revising for your 2014 Public Law exam? Here are some of this year's key developments and blog highlights, Public LAw For Everyone (May 7, 2014).

${ }^{15}$ See Lord Hoffman in R. v. Secretary of State for the Home Department ex parte Simms, [2000] 2AC 115, 131 (claiming that "the courts of the United Kingdom, though acknowledging the sovereignty of Parliament, apply principles of constitutionality little different from those which exist in countries where the power of the legislature is expressly limited by a constitutional document."

${ }^{16}$ In C-221/89 R. Secretary of State v. Factortame [1991] ECJ the European Court of Justice (ECJ), now the Court of Justice of the European Union (CJEU) was asked to consider whether the U.K. Merchant Shipping Act 1998 was incompatible with EC law. The Court ruled that in such circumstances a national court has a duty to grant interim relief to safeguard alleged Community rights of individuals until the decision of the ECJ on the interpretation of Community law is available, and where a rule of national law would deny such relief, to set aside that rule. The U.K. House of Lords subsequently granted Factortame an injunction in effect disapplying the relevant provisions of the 1998 Act. In Jackson v. Attorney General [2006] 1 AC 262 at [102] Lord Steyn opined obiter that if Parliament were to introduce "oppressive and wholly undemocratic legislation"-as for example, by moving to abolish judicial review - then the judges who had created the principle of parliamentary sovereignty might have qualify it, i.e. they might have to consider whether judicial review "is a constitutional fundamental which even a sovereign Parliament acting at the behest of a complaisant House of Commons cannot abolish."

${ }^{17}$ See Jessica Semor Q.C., Is the Civil Law Interpretation of Proportionality Causing the Court to Become Political and Therefore Harder to Predict?, White PaPer Conference, Judicial Review: ShaPing New Law into Solution-Focused ANSWERS FOR YOUR CLIENTS (Apr. 18, 2018).
} 
viability." 18 Attentiveness to these matters "prompts those who cultivate it to keep a weather eye on sources (or potential sources) of practical difficulty." ${ }_{19}$ From this point of view, the Miller judgments with their emphasis on common law principles of rights protection and legality prioritised the legal arguments rather than the political ${ }^{20}$ but stand accused of misjudging contemporary democratic imperatives. As Lord Reed pointed out in his Miller I dissent, "[i]t is important for courts to understand that the legalisation of political issues is not always constitutionally appropriate, and may be fraught with risk, not least for the judiciary." 21

This paper now predicts and comments as follows. Writing in 2018 before the U.K. formally left the European Union, Professor Mullender's focus was Brexit and the changing constitutional relationship between law and politics that Miller I specifically and subsequently Miller II represented. As the coronavirus pandemic sweeps across the globe, and governments, including those of the U.K. use emergency powers to legitimise restrictions on economic and social activity not seen outside of war, Carol Harlow \& Richard Rawlings' well-known comment - "Behind every theory of administrative law there lies a theory of the state" 22 has never been more apposite. The judiciary will almost certainly be called upon to "show the red light' to government actions that infringe individual rights but the constitutional pendulum will be reset and the tension between the judicial and elected branches inherent in the U.K. version of the separation of powers will be resolved in favour of the latter. Judicial review will refocus away from the constitutionalism of recent years in favour of a more traditionally restrained role that will demonstrate respect for the political choices of the electorate's chosen representatives. In this respect, the refusal of the Supreme Court in the recent case of Gallaher ${ }^{23}$ to develop a common law principle of equal treatment may represent a straw in the wind. Lord Carnwath cited with approval the remarks of Lord Hoffmann in the earlier case of Matadeen $v$ Pointu $^{24}$ who framed the issue thus:

Of course persons should be uniformly treated, unless there is some valid reason to treat them differently. But what counts as a valid reason for treating them differently? And, perhaps more important, who is to decide whether the reason is valid or not? Must it always be the courts?

\footnotetext{
${ }^{18}$ Richard Mullender, Transmuting the Politico-Legal Lump: Brexit and Britain's Constitutional Order, 39 CARDOZO L. REV. 1019 (2018).

${ }^{19}$ Id. At 1038 .

${ }^{20}$ In Miller I no judge expressed the view that the matter was non-justiciable.

${ }^{21} \mathrm{R}$ (Miller) v. Sec'y of State for Exiting the European Union (Miller 1) [2017] UKSC 5 [240] (Lord Reed, JSC, dissenting).

${ }^{22}$ Carol Harlow \& Richard Rawlings, LaW AND Administration 46 (3d ed. 2009).

${ }^{23}$ R (Gallagher Group Ltd.) v. Competititon \& Markets Auth. [2018] UKSC 25 [26].

${ }^{24}$ [1999] 1 AC 98 [9] (Lord Hoffmann) (internal citation omitted).
} 
The reasons for not treating people uniformly often involve, as they do in this case, questions of social policy on which views may differ. These are questions which the elected representatives of the people have some claim to decide for themselves. The fact that equality of treatment is a general principle of rational behaviour does not entail that it should necessarily be a justiciable principle — that it should always be the judges who have the last word on whether the principle has been observed. In this, as in other areas of constitutional law, sonorous judicial statements of uncontroversial principle often conceal the real problem, which is to mark out the boundary between the powers of the judiciary, the legislature and the executive in deciding how that principle is to be applied.

As former Supreme Court Justice Jonathan Sumption has observed, this is not a matter of deference but rather a function of two distinct sources: "[o]ne is the constitutional principle of the separation of powers. The other is simply a pragmatic view of the evidential value of some judgments of the executive, in areas where their experience is entitled to weight." 25

Former Law Lord and House of Lords cross bencher Lord Brown of Eaton-underHeywood asserted in the course of debate on the Criminal Justice and Courts Bill that judicial review is not a matter for the legislature. ${ }^{26} \mathrm{With}$ all respect, in our mixed politico-legal order it is the doctrine of the sovereignty of Parliament which in the last analysis will and should give Parliament the upper hand. Parliament has determined on two significant occasions that the scope of judicial review is too important to be left entirely to the judges. ${ }^{27}$ While the second intervention was regarded by members of the senior judiciary as misguided, it is certainly the case that it was the first intervention that marked the beginning of a systemised jurisdiction of judicial review as we know it today and from that point of view must be regarded as positive. In the same way there are choices to be made concerning the allocation of resources and the differential treatment of persons, as above. In a modern democracy these matters are too important to be left entirely to the judges.

\footnotetext{
${ }^{25}$ Lord Sumption, Lord Sumption gives the Administrative Law Bar Association Annual Lecture; Anxious Scrutiny (Nov. 4, 2014).

${ }^{26}$ HL Deb vol 755 col 1440 (28 July 2014), Lord Brown of Eaton-under- Heywood.

27 The new procedure of Application for Judicial Review was introduced initially by changes to civil procedure rules-see SI 1977 No 1955; SI 1980 No 2000 - and is now found in the Senior Courts Act 1981, s 31. The Criminal Justice and Courts Act 2015, Part 4 introduced significant changes to the procedure which have the effect of making it more difficult for charities and campaigning groups to intervene in judicial review proceedings. Notably, under S87 interveners in judicial review proceedings must bear the consequential costs of intervention if :a) the intervenor acts "in substance" as a principal party or b)their intervention is not of "significant assistance" or c) a "significant part" of the intervention is "not necessary for the resolution of the issues" or d) the intervenor has behaved unreasonably". Under S 84 a court "must" refuse to grant permission or relief if it is "highly likely" that he public authority would have made the same decision if it had acted lawfully.
} 


\section{LIST OF ABBREVIATIONS}

CJEU - Court of Justice of the European Union

ECHR - European Court of Human Rights

ECJ - European Court of Justice

HRA - Human Rights Act 1998

\section{REFERENCE LIST}

Adam Tomkins, In Defence of the Political Constitution, 22 OXFORD J. LEG. STUDIES 157-75 (2002).

ADAM TOMKINS, PUBLIC LAW (2003).

Adam Tomkins, What's Left of the Political Constitution, 14 GERMAN L.J. 2275-292 (2013).

C-221/89 R. Secretary of State v. Factortame [1991] ECJ.

Carol Harlow \& Richard Rawlings, 'Striking Back' and 'Clamping Down': An Alternative Perspective on Judicial Review, in PUBLIC LAW ADJUDICATION IN COMMON LAW SYSTEMS: PROCESS AND SubSTANCE 312 (John Bell et al. eds., 2015).

CAROL HARlOW \& RichaRd RAWLings, LAw AND AdMINISTRATION 46 (3rd ed. 2009).

Chris Grayling, The Judicial Review System is not a Promotional Tool for Countless Left-wing Campaigners, DAILY MAIL (Sept. 6, 2013), https://www.dailymail.co.uk/news/article-2413135/CHRISGRAYLING-Judicial-review-promotional-tool-Left-wing-campaigners.html

CONSERVATIVE \& UNIONIST PARTY MANIFESTO (2019), https://assets-global.websitefiles.com/5da42e2cae7ebd3f8bde353c/5dda924905da587992a064ba_Conservative\%202019 $\% 20$ Manifesto.pdf.

Constitution Committee, Criminal Justice and Courts Bill, HL 18 (2014) [6].

Graham Gee \& Gregoire C.N. Webber, What Is a Political Constitution? 30 OXFord J. LEG. STUDIES 273-99 (2010).

HL Deb vol 755 col 1440 (28 July 2014), Lord Brown of Eaton-under- Heywood.

Jackson v. Attorney General [2006] 1 AC 262 at [102].

Jane Croft \& James Blitz, Lawyers Fear Tories Are Planning 'Revenge' Against the Supreme Court, FinANCIAL TiMES (Dec. 11, 2019), https://www.ft.com/content/60f97382-1b4e-11ea-97dfcc63de1d73f4.

Jessica Semor Q.C., Is the Civil Law Interpretation of Proportionality Causing the Court to Become Political and Therefore Harder to Predict? WhITE PAPER CONFERENCE, Judicial REVIEW: SHAPING New LAW INTO SOLUTION-FoCUSED ANSWERS FOR YOUR CLIENTS (Apr. 18, 2018), https://www.matrixlaw.co.uk/wp-content/uploads/2016/03/Does-the-proportionalitytest-make-judges-too-political.pdf.

Lord Sumption, Lord Sumption gives the Administrative Law Bar Association Annual Lecture; Anxious Scrutiny (Nov. 4, 2014), https://www.supremecourt.uk/docs/speech-141104.pdf. 
Mark Elliott, Revising for your 2014 Public Law exam? Here are some of this years's key developments and blog highlights, PUBLIC LAW FOR EVERYONE (May 7, 2014), https://publiclawforeveryone.com/2014/05/07/revising-for-your-public-law-exam-here-aresome-of-this-years-key-developments-and-blog-highlights/

Matadeen v Pointu [1999] 1 AC 98 [9] (Lord Hoffmann) (internal citation omitted).

Michael Dempsey, General Election 2019: Judicial Review Reform for Brexit Britain? BRYAN CAVE LEIGHTON PAISNER (Dec. 3, 2019), https://www.bclplaw.com/en-GB/thoughtleadership/general-election-2019-judicial-review-reform-for-brexit-britain.html.

R (Gallagher Group Ltd.) v. Competititon \& Markets Auth. [2018] UKSC 25 [26].

R (Miller) v. Sec'y of State for Exiting the European Union (Miller 1) [2017] UKSC 5 [240].

R. (Miller) v. Prime Minister [2019] UKSC (41) (Miller II).

R. (Miller) v. Secretary of State for Exiting the European Union [2017] UKSC 5 (Miller I).

R. v. Secretary of State for the Home Department ex parte Simms, [2000] 2AC 115, 131.

Richard Mullender, Transmuting the Politico-Legal Lump: Brexit and Britain's Constitutional Order, 39 CARDOZO L. REV. 1019-038 (2018).

The Criminal Justice and Courts Act 2015. 